\title{
CORRECTION
}

\section{Correction to: Hydrochemical Evolution of the Filling of the Mining Lake of As Pontes (Spain)}

\author{
Ricardo Juncosa $^{1}\left[\right.$ D Jorge Delgado ${ }^{1} \cdot$ Jose Luis Cereijo $^{1} \cdot$ Andrea Muñoz $^{1}$
}

Published online: 23 September 2019

๑) Springer-Verlag GmbH Germany, part of Springer Nature 2019

\section{Correction to: \\ Mine Water and the Environment (2019) 38:556-565 \\ https://doi.org/10.1007/s10230-019-00612-6}

In the original publication the legend was accidentally omitted for Figures 4-10. Each of those figures should have had this legend.

Rainfall $\bigcirc$ North Channel (CPN) $\bigcirc$ West Channel (CEE) $\bigcirc$ South Channel (CPS) $\bigcirc$ Eume $\diamond P V E \diamond P V O \diamond$ LU

The original article can be found online at https://doi.org/10.1007/ s10230-019-00612-6.

Ricardo Juncosa

rjuncosa@udc.es

1 School of Civil Engineering, University of A Coruña,

Campus de Elviña s/n., 15192 A Coruña, Spain 